\title{
Comparison of methods for closure of appendix stump during laparoscopic appendectomy using endoloops: Single surgeon experience
}

\author{
Yahya Çelik, M.D., (1) Ozan Andaç Erbil, M.D.,
}

Department of General Surgery, Gebze Fatih State Hospital, Kocaeli-Turkey

\begin{abstract}
BACKGROUND: In this study, using single or double endoloops, with reference to the literature, we aimed to retrospectively assess the results for patients in our clinic who underwent a laparoscopic appendectomy.

METHODS: This study included 25 I patients who were operated on by a single surgeon; I 37 of the patients were male (54.6\%) and I I 4 were female (45.4\%). Patients were divided into two groups based on the type of endoloop procedure that was used. Group I included 107 patients for whom a single endoloop was used. Group II included I44 patients for whom double endoloop was used. Age, sex, duration of operation, length of hospital stay, pathological findings, perioperative appendix findings, perioperative abdominal findings, post-operative complications requiring hospitalization and wound infections were assessed for each patient. Patients were also assessed statistically for complications.
\end{abstract}

RESULTS: There were no significant differences in the demographic characteristics, perioperative surgery findings, pathological findings or duration of hospital stays between the two groups of the patients. However, the duration of operation was shorter in Group I $(54.9 \pm 16.1 \mathrm{~min})$ as compared to Group II (6I.2 I I8.8 $\mathrm{min})$. The incidence of complications requiring rehospitalization was statistically significantly lower in Group I $(1.9 \% ; n=2)$ as compared to Group II $(9 \% ; n=13)(p=0.018)$. There were no complications requiring reoperation for patients in Group I. In Group II, four patients (2.8\%) required re-operation; however, this difference was not statistically significant. Concerning wound infection, there was also no significant difference between Group I (7.5\% n=8) and Group II (4.9\% $\mathrm{n}=7)$.

CONCLUSION: Using a double endoloop does not decrease the risk of post-operative complications, but it does increase the cost and the duration of the operation. We have concluded that using a single endoloop in a laparoscopic appendectomy may be more appropriate.

Keywords: Appendix; closure of stump; endoloop; laparoscopic appendectomy.

\section{INTRODUCTION}

Acute appendicitis is the most prevalent acute abdominal disease and the gold standard of treatment is surgical excision. ${ }^{[I]}$ The laparoscopic appendectomy method was first published in the literature by Semm in 1983. ${ }^{[2]}$ In addition to open and laparoscopic surgical methods, single-incision laparoscopic surgery (SILS) and natural orifice transluminal endoscopic appendectomy (NOTES) methods were also described for surgical treatment of acute appendicitis. ${ }^{[1,3-5]} \mathrm{Clo-}$ sure of the appendix stump is the most controversial area in the surgical technique because most appendectomy complications are the result of stump leakage. Various methods, such as endostaplers, pre-assembled endoloops or intracorporeal knots, endoclips and Hem-o-lok, were described for laparoscopic appendectomy procedures and are still currently in use. ${ }^{[6-9]}$ In this series, a double endoloop was used for some patients and a single endoloop was used for others.

Cite this article as: Çelik Y, Erbil OA. Comparison of methods for closure of appendix stump during laparoscopic appendectomy using endoloops: Single surgeon experience. Ulus Travma Acil Cerrahi Derg 2019;25:616-621.

Address for correspondence: Yahya Çelik, M.D.

Gebze Fatih Devlet Hastanesi, Genel Cerrahi Kliniği, Kocaeli, Turkey

Tel: +90 262 - 5022237 E-mail: dryahyacelik@mynet.com

Ulus Travma Acil Cerrahi Derg 2019;25(6):616-621 DOI: 10.14744/tjtes.2019.63249 Submitted: 21.09.2018 Accepted: 04.02.2019 Online: 30.10.2019 Copyright 2019 Turkish Association of Trauma and Emergency Surgery 
[10-15] However, publications comparing the double endoloop or intracorporeal knot method with a single endoloop or intracorporeal knot method are scarce. ${ }^{[6]}$ In our study, we aimed to retrospectively assess the results for the patients in our clinic who underwent a laparoscopic appendectomy using a single or double endoloop, with reference to the literature.

\section{MATERIALS AND METHODS}

After obtaining the approval of the local ethics committee, patient charts and computer data were retrospectively assessed. Patients whose operations started laparoscopically but then switched to open surgery and patients in whom endoloop was not used due to cecal necrosis, were excluded from this study. The final series included 25 I patients (I37 male and II 4 female) who had undergone a laparoscopic appendectomy, performed by single-surgeon (general surgeon, Y. Ç.) between July 2014 and July 2018. Endoloop was used in each of these patients, regardless of the perioperative appendix findings (phlegmonous, perforated).

Patients were assessed in concerning age, sex, duration of operation, length of hospital stay, pathological findings, perioperative appendix findings, perioperative abdominal findings, post-operative complications requiring hospitalization and wound infections. They were then divided into two groups according to the use of single or double endoloop techniques. Group I consisted of 107 patients for whom a single endoloop ligature was used. Group II consisted of I44 patients for whom a double endoloop ligature was used.

Demographic characteristics, perioperative surgical findings, pathological findings, post-operative findings and complications were statistically compared between the two groups and assessed with reference to the literature.

\section{Surgery}

Pre-operative prophylactic cephazolin sodium I g was administered to the patients intravenously. Under general anesthesia, pneumoperitoneum was created by inserting a veres needle through the infraumbilical incision, thus enabling the $10 \mathrm{~mm}$ trocar to enter the abdomen. Two $5 \mathrm{~mm}$ trocars were inserted in the left lower quadrant and suprapubically, under direct vision. The abdomen was explorated with a $10 \mathrm{~mm}$ and $30 \mathrm{~mm}$ optic and the meso-appendix was separated using LigaSure (Medtronic). For patients in Group II, after the radix of the appendix became visible, the endoloop (Medtronic 0 vicryl) was ligated in a double endoloop, with 3-5 mm space between the ligatures. For patients in Group I, no additional procedure was carried out. The distal end was dissected by closing with the assistance of a dissector (Fig. I). Optic 5 $\mathrm{mm}$ was switched with $18 \mathrm{~cm}$ and the appendix was removed through the $10 \mathrm{~mm}$ umbilical trocar or with the assistance of an endobag. If present, intraabdominal fluid or pus was

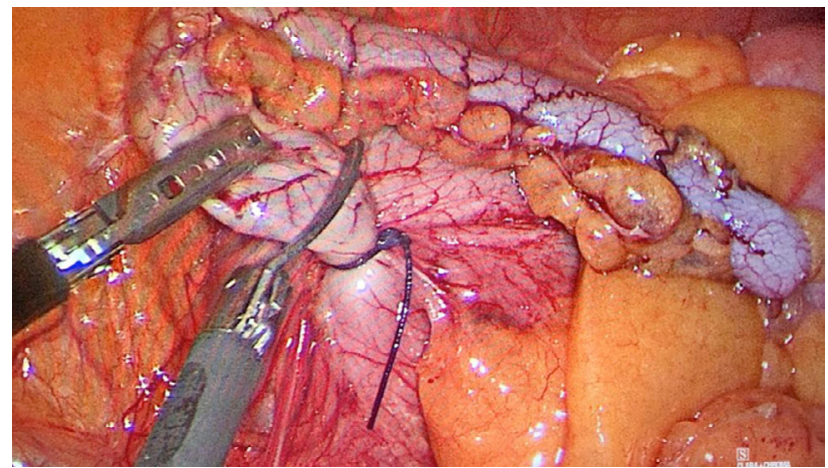

Figure 1. Use with single endoloop.

aspirated and then a drain was inserted. For patients with perforation, antimicrobial therapy was administered during the hospital stay and continued until 10 days after discharge. Antimicrobial therapy was not sustained after prophylactic therapy in non-perforated patients.

\section{Statistical Methods}

Statistical analysis was conducted using the SPSS version 17.0 program. The conformance of the variables to normal distribution was controlled using histogram graphics and the Kolmogorov-Smirnov test. Mean, standard deviation, median and minimum-maximum values were used for descriptive analysis. The results were compared in $2 \times 2$ cells using Pearson Chi-Square and Fisher's Exact Test. The Mann-Whitney $U$ test was used to assess variables without normal distribution (non-parametric) between groups. Results with a p-value $<0.05$ were considered statistically significant.

\section{RESULTS}

The $25 \mathrm{I}$ patients in the series included 137 male (54.6\%) and I 14 female (45.4\%) patients. The single endoloop technique was used in the 107 patients assigned to Group I. The double endoloop technique was used for the remaining 144 patients, who were assigned to Group II. The mean age of the patients was $32.2 \pm 1 \mid .3$ years. A comparison of patient age, and duration of operation and hospital stay between the two groups found that the duration of operation was longer in Group II (6I I $2 \pm$ I $8.8 \mathrm{~min}$ ) compared to Group I (54.9 \pm I6. I $\min )(p=0.001)$, but there was no statistically significant difference concerning patient age and length of hospital stay $(p>0.05)$.

When pathological findings were compared for patients in each group, the incidence of acute/phlegmonous appendicitis $(62.6 \%)$ was found to be higher in patients in Group I than in Group II (49.3\%) $(p=0.004)$ (Table I).

No significant difference was found in a comparison of perioperative appendix findings $(p>0.05)$ (Table I), pre-operative abdominal findings or drain use $(p>0.05)$ for patients in Group I and Group II. 
Table I. Pathological findings. perioperative appendix findings, perioperative appendix findings and incidence of the complications

\begin{tabular}{|c|c|c|c|c|c|}
\hline & \multicolumn{2}{|c|}{$\begin{array}{c}\text { Group I } \\
\text { (Single endo-loop) }\end{array}$} & \multicolumn{2}{|c|}{$\begin{array}{c}\text { Group II } \\
\text { (Double-endoloop) }\end{array}$} & \multirow[t]{2}{*}{$\mathbf{p}$} \\
\hline & $\mathbf{n}$ & $\%$ & $\mathbf{n}$ & $\%$ & \\
\hline \multicolumn{6}{|l|}{ Pathological findings of the patients } \\
\hline Appendicitis/phlegmonous & 67 & 62.6 & 71 & 49.3 & 0.004 \\
\hline Perforated & 0 & 0.0 & 3 & 2.1 & \\
\hline Appendix obliterans & 3 & 2.8 & 6 & 4.2 & \\
\hline Phlegmonous + lymphoid hyperplasia & 31 & 29.0 & $4 I$ & 28.5 & \\
\hline Pathology result non-available. & 3 & 2.8 & 23 & 16.0 & \\
\hline Neuroendocrine tumour & 2 & 1.9 & 0 & 0.0 & \\
\hline \multicolumn{6}{|l|}{ Phlegmonous + lymphoid hyperplasia + } \\
\hline enterobius vermicularis & 1 & 0.9 & 0 & 0.0 & \\
\hline \multicolumn{6}{|l|}{ Perioperative appendix findings } \\
\hline \multicolumn{6}{|l|}{ Peri-operative appendix } \\
\hline Normal & 0 & 0.0 & I & 0.7 & 0.488 \\
\hline Phlegmonous acute app & 80 & 74.8 & III & 77.1 & \\
\hline Gangrene & 8 & 7.5 & 5 & 3.5 & \\
\hline Perforated & 19 & 17.8 & 26 & 18.1 & \\
\hline \multicolumn{6}{|c|}{ Perioperative appendix findings of thepatients and drain use } \\
\hline \multicolumn{6}{|l|}{ Peri-operative abdominal } \\
\hline Normal & 83 & 77.6 & 110 & 76.4 & 0.479 \\
\hline Reaction fluid & 8 & 7.5 & 17 & 11.8 & \\
\hline Local pus/abscess & 11 & 10.3 & 14 & 9.7 & \\
\hline Widespread pus/abscess & 5 & 4.7 & 3 & 2.1 & \\
\hline Drain & 26 & 24.3 & 31 & 21.7 & 0.635 \\
\hline \multirow{2}{*}{\multicolumn{6}{|c|}{$\begin{array}{l}\text { Incidence of complications requiring rehospitalization, } \\
\text { requiring re-operation and wound infection }\end{array}$}} \\
\hline & & & & & \\
\hline \multicolumn{6}{|l|}{ Re-hospitalization } \\
\hline No & 105 & 98.1 & $|3|$ & 91.0 & 0.018 \\
\hline Yes & 2 & 1.9 & 13 & 9.0 & \\
\hline \multicolumn{6}{|l|}{ Complication } \\
\hline Subileus & 2 & 1.9 & 7 & 4.9 & 0.212 \\
\hline Abdominal pain monitorization & 0 & 0.0 & 2 & $\mathrm{I} .4$ & \\
\hline Stump leakage & 0 & 0.0 & I & 0.7 & \\
\hline Trocar site hernia & 0 & 0.0 & 1 & 0.7 & \\
\hline Intraabdominal abscess & 0 & 0.0 & 2 & 1.4 & \\
\hline Requiring re-operation & 0 & 0.0 & 4 & 2.8 & 0.082 \\
\hline Wound infection & 8 & 7.5 & 7 & 4.9 & 0.387 \\
\hline
\end{tabular}

The incidence of wound infections or complications requiring rehospitalization or re-operation were compared. Patients in Group II required rehospitalization at a significantly higher rate $(9 \%)$ than patients in Group I $(1.9 \%)(p=0.018)$. There were no differences in the rate of wound infection and in the number of patients requiring re-operation between the groups $(p>0.05)$ (Table I).
In patients requiring rehospitalization, the perforated appendicitis rate $(30.8 \%)$ as a perioperative appendix sign was higher than in patients that did not require rehospitalization (17.6\%). The incidence of gangrene for patients requiring rehospitalization (15.4\%) was also higher than in patients that did not require rehospitalization (2.3\%). In patients requiring rehospitalization, the incidence of normal/phlegmonous 
acute appendicitis (53.8\%) as a perioperative appendix sign was lower than in patients that did not require rehospitalization $(80.2 \%)(p=0.018)$.

In patients requiring re-operation, the perforated appendicitis rate $(25 \%)$ was higher than in patients that did not require re-operation (18.6\%). In patients requiring re-operation, the incidence of gangrene was higher $(25 \%)$ when compared to patients that did not require re-operation (2.9\%). In patients requiring re-operation, the rate of normal/phlegmonous acute appendicitis $(50 \%)$ was lower than in patients that did not require re-operation $(78.6 \%)(p=0.050)$.

In Group I, 2 patients requiring rehospitalization had subileus as a complication. In Group II, 13 patients requiring rehospitalization had the following complications: subileus $(n=7)$, abdominal pain monitorization $(n=2)$, stump leakage $(n=1)$, trocar site hernia $(n=I)$ and intraabdominal abscess $(n=2)$. In Group II, four patients requiring re-operation, the complications were as follows: stump leakage $(n=1)$, trocar site hernia $(n=l)$ and intraabdominal abscess $(n=2)$. Two patients diagnosed with intraabdominal abscess required open drainage. Incisional hernia surgery was performed on a patient with a trocar site hernia diagnosis. Another patient required reoperation to re-close the appendix stump after a diagnosis of stump leakage. After draining and cleaning the abdomen, a preventive ileostomy was carried out and, three months later, the ileostomy was closed.

\section{DISCUSSION}

There were no significant differences between the two groups in our series concerning demographic characteristics, pathological findings, perioperative appendix findings and duration of hospital stay.

In the study by Rakić et al., ${ }^{[13]}$ a comparison of the single proximal endoloop and endostapler techniques found that there were no differences between the two groups concerningperioperative or post-operative complications. The duration of operation, however, was shorter in endoloop patients. In their study comparing single proximal endoloop and Hem-o-lock clips, Lucchi et al. ${ }^{[12]}$ found that patients in both groups experienced a similar length of hospital stay and the rate of infectious complications. Bali et al. ${ }^{[16]}$ compared the use of double intracorporeal knots and endoloops and found that the duration of operation was higher when the intracorporeal knot was used, but there was no difference in the rate of complications. In the study by Rossem et al. ${ }^{\left[{ }^{[I]}\right]}$ comparing the use of double proximal endoloops and endostaplers, no significant difference was observed between the two groups about duration of operation and infectious complications. In the study by Swank et al. ${ }^{[15]}$ comparing the use of double or single endoloops with endostaplers, no significant difference was found in the rate of post-operative infectious complications. The results reported by other authors are summarized in Table 2 .

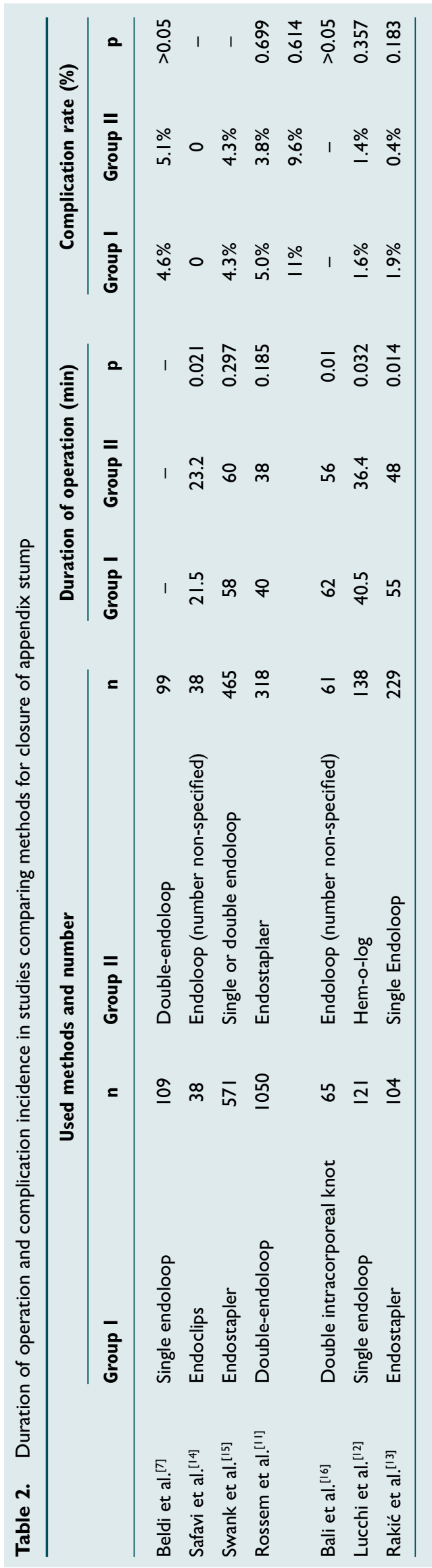


In a study of 208 patients by Beldi et al., ${ }^{[7]}$ a single endoloop was used in 109 patients, while double endoloop was used in the remaining 99 patients. Post-operative complications occurred in five patients $(4.6 \%)$ in the single endoloop group and in five patients $(5.1 \%)$ in the double endoloop group. Although the rate of complication was lower in the single endoloop group, the difference was not statistically significant. Repeat studies over a larger series were suggested. In our series, the rate of complications requiring rehospitalization was significantly lower in Group I $(n=2,1.9 \%)$ compared to Group II $(n=13,9 \%)$. There were no complications requiring re-operation in Group I, but four patients in Group II experienced complications requiring re-operation (two patients had intraabdominal abscesses, one patient had stump leakage and one patient had an incisional hernia). The difference between the two groups, however, was not significant.

In the study by Rossem et al., ${ }^{[1]}$ necrosis or perforation of the appendicitis was considered complicated appendicitis. Complicated appendicitis was found to be a risk factor for the development of an intraabdominal abscess. In our series, there was no difference between the two groups about perioperative appendix findings. However, in the whole series, the rate of complicated appendicitis was higher in patients with complications due to surgery, as compared to patients without complications.

In our series, the mean duration of operation was shorter in

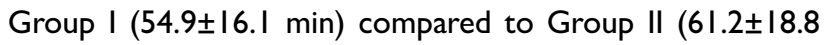
$\mathrm{min})$. We think that the difference may be the result of additional time needed to insert the second loop.

In conclusion, endoloop use is as safe as other methods in laparoscopic appendectomy. Using a double endoloop does not decrease the rate of post-operative complications; however, it increases the cost and duration of the operation. Therefore, we have concluded that using a single endoloop in a laparoscopic appendectomy may be more appropriate.

\section{Conflict of interest: None declared.}

\section{REFERENCES}

1. Ruffolo C, Fiorot A, Pagura G, Antoniutti M, Massani M, Caratozzolo E, et al. Acute appendicitis: what is the gold standard of treatment? World J Gastroenterol 2013;19:8799-807.[CrossRef]

2. Semm K. Endoscopic appendectomy. Endoscopy 1983;15:59-64.
3. Sauerland S, Jaschinski T, Neugebauer EA. Laparoscopic versus open surgery for suspected appendicitis. Cochrane Database Syst Rev 2010;10:CD001546. [CrossRef]

4. Cai Y-L, Xiong X-Z, Wu S-J, Cheng Y, Lu J, Zhang J, et al. Single-incision laparoscopic appendectomy vs conventional laparoscopic appendectomy: systematic review and meta-analysis. World J Gastroenterolo 2013;19:5165-73. [CrossRef]

5. Sateesh S, Subraj H, Mahesh G, Rao PS. Comparative analysis between single incision and conventional laparoscopic appendectomy for acute appendicitis. Int J Res Med Sci 2014.2:1626-31. [CrossRef]

6. Minutolo V, Licciardello A, Di Stefano B, Arena M, Arena G, Antonacci V. Outcomes and cost analysis of laparoscopic versus open appendectomy for treatment of acute appendicitis: 4-years experience in a district hospital. BMC surgery 2014;14:14. [CrossRef]

7. Beldi G, Muggli K, Helbling C, Schlumpf R. Laparoscopic appendectomy using endoloops: a prospective, randomized clinical trial. Surg Endosc 2004;18:749-50. [CrossRef]

8. Tate JJ, Chung SC, Li AK. Laparoscopic appendicectomy: a two-handed technique. Br J Surg 1993;80:764. [CrossRef]

9. Partecke LI, Kessler W, von Bernstorff W, Diedrich S, Heidecke CD, Patrzyk M. Laparoscopic appendectomy using a single polymeric clip to close the appendicular stump. Langenbecks Arch Surg 2010;395:107782. [CrossRef]

10. Delibegović S, Matović E. Hem-o-lok plastic clips in securing of the base of the appendix during laparoscopic appendectomy. Surg Endosc 2009;23:2851-4. [CrossRef]

11. van Rossem CC, van Geloven AA, Schreinemacher MH, Bemelman WA, snapshot appendicitis collaborative study group. Endoloops or endostapler use in laparoscopic appendectomy for acute uncomplicated and complicated appendicitis. Surg Endosc 2017;31:178-84. [CrossRef]

12. Lucchi A, Berti P, Grassia M, Siani LM, Gabbianelli C, Garulli G. Laparoscopic appendectomy: Hem-o-lok versus Endoloop in stump closure. Updates Surg 2017;69:61-5. [CrossRef]

13. Rakić M, Jukić M, Pogorelić Z, Mrklić I, Kliček R, Družijanić N, et al. Analysis of endoloops and endostaples for closing the appendiceal stump during laparoscopic appendectomy. Surg Today 2014;44:1716-22.

14. Sadat-Safavi SA, Nasiri S, Shojaiefard A, Jafari M, Abdehgah AG, Notash AY Jr, et al. Comparison the effect of stump closure by endoclips versus endoloop on the duration of surgery and complications in patients under laparoscopic appendectomy: A randomized clinical trial.J Res Med Sci 2016;21:87. [CrossRef]

15. Swank HA, van Rossem CC, van Geloven AA, Kazemier G, Meijerink WJ, Lange JF, et al. Endostapler or endoloops for securing the appendiceal stump in laparoscopic appendectomy: a retrospective cohort study. Surg Endosc 2014;28:576-83. [CrossRef]

16. Bali İ, Karateke F, Özyazıcı S, Kuvvetli A, Oruç C, Menekşe E, et al. Comparison of intracorporeal knotting and endoloop for stump closure in laparoscopic appendectomy. Ulus Travma Acil Cerrahi Derg 2015;21:446-9. [CrossRef] 


\section{ORİIINAL ÇALIŞMA - ÖZET}

\section{Laparoskopik apendektomilerde endoloop ile güdük kapama tekniği karşılaştırılması:} Tek hekim deneyimi

\section{Dr. Yahya Çelik, Dr. Ozan Andaç Erbil}

Gebze Fatih Devlet Hastanesi, Genel Cerrahi Kliniği, Kocaeli

AMAÇ: Bu çalışmada kliniğimizde çift ya da tek endoloop kullanılarak laparoskopik apendektomi yapılan hastalarımızın sonuçlarını literatür eşliğinde geriye dönük olarak değerlendirmeyi amaçladık.

GEREÇ VE YÖNTEM: Çalışmaya I37 erkek (\%54.6) ve II4 kadın (\%45.4) olmak üzere tek cerrah tarafından ameliyat edilen toplam 25 I hasta katıldı. Hastaların I07'si tek endoloop yönteminin kullanıldığı grup I, I44'ü çift endoloop yönteminin kullanıldığı grup II idi. Hastaların yaş cinsiyet, ameliyat süresi, hastanede yatma süresi, patoloji bulguları, perioperatif apendiks bulguları, perioperatif batın bulguları, ameliyat sonrası yatış gereken komplikasyonlar, ameliyat sonrası operasyon gereken komplikasyonlar ve yara yeri enfeksiyonuna bakıldı. Komplikasyonlar istatistiksel olarak incelendi.

BULGULAR: Her iki grup arasında demografik özellikler, perioperatif ameliyat bulguları, patoloji bulguları, ameliyat sonrası bulgular ve hastanede yatış süreleri arasında anlamlı fark izlenmedi. Ameliyat süreleri grup l'de $(54.9 \pm \mid 6,1)$ grup Il'den $(6 \mid .2 \pm 18,8)$ daha kısa bulundu. Tekrar yatış gerektiren komplikasyonlar grup l'de $(\% /, 9 ; n=2)$ grup Il'den $(\% 9 ; n=13)$ anlamlı olarak az bulundu $(p=0.018)$. Tekrar ameliyat gereken komplikasyon grup l'de olmadı. Grup II'de dört hastada (\%2.8) oldu, İstatistiksel olarak anlamlı fark bulunmadı. Yara yeri enfeksiyonu grup I (\%7.5 $\mathrm{n=8}$ ) ile grup II (\%4.9 $n=7)$ arasında anlamlı fark izlenmedi.

TARTIŞMA: Çift endoloop kullanmak ameliyat sonrası komlikasyonları azaltmamakla birlikte ameliyat maliyetini artırmakta ve ameliyat süresini uzatmaktadır. Laparoskopik apendektomide loop kullanımında tek loop kullanmanın daha uygun olacağı kanaatindeyiz.

Anahtar sözcükler: Apendisit; endoloop; güdük kapama; laparoskopik apendektomi.

Ulus Travma Acil Cerrahi Derg 2019;25(6):616-621 doi: 10.14744/tjtes.2019.63249 